\title{
Geneticist trades plants for politics
}

Nina Fedoroff is a plant geneticist who has won many accolades for her work in crop productivity and is a staunch proponent of sowing genetically modified (GM) crops in Africa. She could now be facing her toughest challenge yet. Fedoroff is the new science and technology adviser to US Secretary of State Condoleezza Rice.

The woman who was the first to clone transposons - segments of DNA that can switch position on the genome, changing the expression of genes - is now charged with briefing Rice and other officials on the scientific aspects of foreign policy and improving science literacy in the department. But some of her well known opinions could cause friction. She's opposed to the push to produce ethanol from maize (corn), which the Bush administration supports. And her stance on genetic engineering contrasts with those of many African countries and of the Alliance for a Green Revolution for Africa, a partnership founded by the Rockefeller Foundation and the Bill \& Melinda Gates Foundation.

Fedoroff, who recently won a National Medal of Science, is also an author of Mendel in the Kitchen (National Academy Press, 2004), which argues that GM crops are the most environmentally responsible way to feed the world.

You use the phrase 'molecular modification' rather than 'genetic engineering'. Why?

I think part of the reason that people go 'eew!' is because engineering is something that we do to buildings, not to plants. All of agriculture, all of modifying plants to suit people as opposed to their own survival, is about molecular modification.

\section{Are GM crops high on your agenda?}

Yes. I will use as much influence as I have to promote that issue. Africa was left behind by the green revolution. We are up against the limits of what we can do on the planet. The amount of land under cultivation has, to a first approximation, not changed in more than half a century. And we are adding around 70 million people a year. Where do people think the food will come from? My basic belief is that we can't solve the political problems of the world as long as we have people that can't grow as much food as they consume.

\section{Will biotechnology help food crops adapt to climate change?}

We don't know what is going to happen with climate change, but stressing plants decreases their productivity. The plant hunkers down and tries to survive. So understanding the relationship between stress and depositing sugar as starch - which is what productivity is about - is really important. How do you increase tolerance of stress, whether from drought or extremes of temperature, without compromising productivity?

\section{So how do you see that field developing?}

It is a complicated issue and the funding is pathetic. It has now moved into the private sector, and companies are in the business of making money, not sharing science.

\section{What's your stance on maize ethanol?} People need to understand that if you grow maize for ethanol, you drive up the price of the maize. Brazil turns sugar into ethanol and it drives up the price of sugar. Now the World Food Programme can buy less and feed fewer people. Ethanol from maize is not going to solve the world's energy problems, it is going to exacerbate them. And ethanol combustion produces the same carbon dioxide emissions as gasoline. Besides, think about the millions of years of photosynthesis that are deposited in oil that we burned through in 100 years. You can't recreate that process from an annual photosynthetic harvest.

Are you going to be able to voice your opinions publicly on matters like this without checking with the administration first?

I don't know. Ask me in six months. But I am a person who tends to work behind the scenes.

\section{What will you focus on first?}

There is a huge number of issues. On my first day of work I am going to a briefing on the state of containment of polio. There's smallpox, there's bird flu. Whether it is global climate change, agriculture, disease - all these things are so intertwined...

\section{Do you fear that you will be asked to politicize science?}

I simply don't know what I'll be asked. I think the only sensible way I can answer is that in politics short-term goals often win out over long-term goals, and that is certainly the determining factor in many decisions. I know that there are a lot of rumours about the politicization of science, and I think I would not be responsible if I said I know what the truth is. Interview by Emma Marris 